Applicants whose family history indicates that they are at risk of developing a particular genetic disorder, for example Huntington's disease or Friedreich's ataxia, are treated in the same way as if the disease were already expressed but with the risk premium correspondingly modified. In many cases the exact status of the applicant could be clarified by the use of DNA testing, but this must neither be requested nor required by the insurance companies according to the Austrian gene technique law (see quotation above). Consequently, the companies will not pay for such tests even if the applicant requests them. However, it may well be to his advantage to provide such information at his own expense. If it is positive he is not worse off, will pay the higher premium, and cover will remain subject to the same restrictions. If the results are negative, then the genetic problem is irrelevant, there would be no restrictions on the policy, and the premium would be normal. Of course this economic argument is only one of many, for example, religious, ethical, psychological, and social, which he would need to consider in coming to a decision.

This enquiry indicates that the existence of a law prohibiting insurers from using genetic test information does not necessarily prevent an applicant for insurance from using that information to his own advantage.

GERTRUD HAUSER ASTRID JENISCH Histologisch-Embryologisches Institut Schwarzspanierstrasse 17, 1090 Vienna, Austria

\section{Microsatellite markers for the cone-rod retinal dystrophy gene, CRX, on 19q13.3}

A large proportion of cases of visual loss in children in the developed world result from genetic aetiologies. Fifty percent of blindness in children in the United Kingdom has been classified as genetic, ${ }^{1}$ of which chorioretinal dystrophies are the most common subgroup; all are untreatable and incurable.

The cone-rod retinal dystrophy (CORD2; MIM 120970) locus on 19q13 is an example of a severe, early onset (first decade of life), choroidoretinal dystrophy, often leading to complete loss of visual function by middle age. ${ }^{23}$ Mutations in a retina specific OTXlike homeobox gene, CRX, that codes for a 299 amino acid protein have recently been shown to be the causative defect for cone-rod dystrophies linked to the $19 \mathrm{q} 13$ locus. Two mutations are described: a highly conserved glutamate at the first amino acid of the recognition sequence of the homeodomain is replaced by an alanine, and a 1 bp deletion leading to a protein truncated by 132 amino acid residues. ${ }^{4}$ We have, however, failed to determine a mutation in the three published coding exons of $1.4 \mathrm{~kb}$ of the CRX mRNA in the original CORD2 family described by Evans et al. ${ }^{2}$ This type of anomaly is not unknown in retinal dystrophies; for example, approximately one third of European choroideremia patients have no known mutation in the rab escort protein-1 (REP-1) coding region. ${ }^{5}$ Similarly, only $10-15 \%$ of X linked retinitis pigmentosa 3 (RP3) patients have a mutation in the retinitis pigmentosa GTPase regulator (RPGR) gene. ${ }^{6}$

In order to determine whether a similar phenomenon is occurring at the CORD2 locus, we have finely mapped the CRX gene to a $285 \mathrm{~kb}$ yeast artificial chromosome (4X11A7) isolated from the ICRF library ${ }^{8}$ that is positive for the polymorphic microsatellite markers D19S902 and C19S17." D19S902 is a Genethon marker with a heterozygosity of $79 \%{ }^{10}$ and C19S17 (GenBank G29026) is a novel microsatellite with an observed heterozygosity of 53\%, "1 amplified by primers 5'-TCA TGA ATT AAT CCC AGG AG-3' and 5'-CTG TAT CTT GGA TAA AGT GG-3' under previously described conditions. ${ }^{12}$ Both of these polymorphic markers are non-recombinant in the original CORD2 family and newly ascertained branches refine the locus further to a $2 \mathrm{cM}$ interval between polymorphic markers D19S412 and glycogen synthase-1 (GYS1). We propose that investigators wishing to determine whether a cone-rod retinal dystrophy pedigree is linked to the $19 \mathrm{q} 13.3$ locus should attempt linkage with either D19S902 or C19S17. The close proximity of D19S902 and C19S17 to the CRX gene should enable other investigators to achieve a lod score indicative of linkage, such as 2 (depending upon pedigree size and structure and polymorphic marker information), which can be taken to be confirmation of a previous linkage. ${ }^{13}$ If these two polymorphic markers are uninformative, we suggest using any of the following polymorphic markers: D19S219, D19S112, D19S412, D19S606, D19S879, D19S604, or D19S246, the flanking polymorphic markers D19S219 and D19S246 encompassing approximately 5 cM of the CORD2 locus. ${ }^{14}$ It is then hoped that a greater spectrum of mutations in the CRX gene may be determined by other laboratories, and our own observations of a lack of a mutation in the presently known sequence may also be confirmed. In the case of the original CORD2 family, the mutation may lie in an as yet undetermined noncoding exon or an upstream regulatory element. We are currently investigating this area since northern analysis of the CRX gene shows two retina specific transcripts, one highly expressed at $4.5 \mathrm{~kb}$ and a second, less highly transcribed mRNA of about $3 \mathrm{~kb}$, though only $1.4 \mathrm{~kb}$ of mRNA sequence is known. ${ }^{4}$ Mutations in regulatory elements have been shown to cause blue cone monochromacy ${ }^{15}$ and forced expression of CRX affects rat retinal cell differentiation in vivo. ${ }^{16}$ Alternatively, the CORD2 locus may be exhibiting microheterogeneity, that is, there may be a mutation in another gene within the CORD2 interval that may be causing the phenotype, as postulated by Fujita $e t$ al in order to explain the lack of mutations observed in the RPGR gene in RP3 patients.

This work was supported by The Wellcome Trust (04385/Z/95).

JAMES BELLINGHAM CHERYL Y GREGORY-EVANS Department of Molecular Genetics, Division of Biomedical Sciences, Imperial College School of Medicine, Norfolk Place, LondonW2 1PG, UK

KEVIN GREGORY-EVANS Casey Eye Institute, Oregon Health Sciences University, 3375 SW Terwilliger Boulevard, Portland, OR 97201, USA
1 Elston J. Epidemiology of visual handicap in children. In: Taylor D, ed. Paediatric ophthalmology. Oxford: Blackwell Scientific Press, 1992:3-6.

2 Evans K, Fryer A, Inglehearn C, et al. Genetic linkage of cone-rod retinal dystrophy to chromosome $19 q$ and evidence for segregation distortion. Nat Genet 1994;6:210-13.

3 Evans K, Duvall-Young J, Fitzke FW, Arden GB, Bhattacharya SS, Bird AC. Chromosome GB, Bhattacharya SS, Bird AC. Chromosome 19q cone-rod retinal dystrophy. Ocular ph

4 Freund CL, Gregory-Evans CY, Furukawa T, er al. Cone-rod dystrophy due to mutations in a novel photoreceptor-specific homeobox gene $(C R X)$ essential for maintenance of the photoreceptor. Cell 1997;91:543-53.

5 van den Hurk JAJM, Schwartz $M$, van Bokhoven $\mathrm{H}$, et al. Molecular basis of choroideremia (CHM): mutations involving the rab escort protein-1 (REP-1) gene. Hum Mutat 1997;9:110-17.

6 Meindl A, Dry K, Herrmann K, et al. A gene $(R P G R)$ with homology to the $R C C 1$ guanine nucleotide exchange factor is mutated in $\mathrm{X}$-linked retinitis pigmentosa (RP3). Nat Genet 1996;13:35-42.

7 Fujita R, Buraczynska M, Gieser L, et al. Analysis of the RPGR gene in 11 pedigrees with the retinitis pigmentosa type 3 genotype: paucity of mutations in the coding region but splice defects in two families. Am 7 Hum Genet 1997; 61:571-80.

8 Larin Z, Monaco AP, Lehrach $\mathrm{H}$. Yeast artificial chromosome libraries containing large inserts from mouse and human DNA. Proc Natl Acad Sci USA 1991;88:4123-7.

9 Bellingham J, Wijesuriya SD, Evans K, Fryer A Bellingham J, Wijesuriya SD, Evans K, Fryer A,
Lennon G, Gregory CY. Genetic and physical Lennon G, Gregory CY. Genetic and physical dystrophy (CORD2). In: LaVail MM, Hollydystrophy (CORD2). In: LaVail MM, Holly-
field JG, Anderson RE, eds. Degenerative retinal field JG, Anderson RE, eds. Degenerative retinal 302

10 Dib C, Faure S, Fizames C, et al. A comprehen sive genetic map of the human genome based on 5,264 microsatellites. Nature 1996;380:1524.

11 Wijesuriya SD. Molecular analysis of inherited choroidoretinal dystrophies. $\mathrm{PhD}$ Thesis, University of London, 1997

12 Wijesuriya SD, Evans K, Jay MR, et al. Sorsby's fundus dystrophy in the British Isles: demonstration of a striking founder effect by stration of a striking founder effect by Res 1996;6:92-101.

13 Terwilliger JD, Ott J. Handbook of human genetic linkage. Baltimore: The Johns Hopkins University Press, 1994

14 Gregory CY, Evans K, Whittaker JL, Fryer A, Weissenbach J, Bhattacharya SS. Refinemen of the cone-rod retinal dystrophy locus on chromosome 19q. Am $\mathcal{F}$ Hum Genet 1994;55 1061-3.

15 Nathans J, Davenport CM, Maumenee IH, et al. Molecular genetics of human blue cone monochromacy. Science 1989;245:831-8.

16 Furukawa T, Morrow EM, Cepko CL. Crx, a novel $o t x$-like homeobox gene shows photoreceptor specific expression and regulates photoreceptor specific expression and regulates photo-

Newer Aspects of Trace Element

Research

The Fifth Conference of the International Society for Trace Element Research in Humans (ISTERH) on "Newer Aspects of Trace Element Research" will be held on 26-30 September 1998 at the newly established "Trace Element - Institute for UNESCO", Lyon, France. For further details contact: Trace Element - Institute for UNESCO, Immeuble Le Condorcet, 1 place de l'Ecole, BP 7021, 69342 Lyon Cedex 07, France. Tel: 33 (0) 4728082 90, fax: $33(0)$ 478588671 , e-mail: 101711.2322@compuserve.com 